\title{
Electrosynthesis and Catalytic Activity of Polymer-Nickel Particles Composite Electrode Materials
}

\author{
Tahar Melki, ${ }^{a}$ Ahmed Zouaoui, ${ }^{a}$ Barkahoum Bendemagh, ${ }^{a}$ Ione M. F. de Oliveira, ${ }^{b}$ \\ Gilver F. de Oliveira, ${ }^{b}$ Jean-Claude Leprêtre, ${ }^{c}$ Christophe Bucher ${ }^{d}$ and Jean-Claude Moutet ${ }^{*, d}$
}

\author{
${ }^{a}$ Département du Tronc Commun, Faculté des Sciences de l'Ingénieur, Université Ferhat Abbas, Sétif, Algeria \\ ${ }^{b}$ Departamento de Química, Universidade Federal de Minas Gerais, 31270-901 Belo Horizonte-MG, Brazil \\ ${ }^{c}$ Laboratoire d'Electrochimie et de Physicochimie des Matériaux et Interfaces, UMR-5631 CNRS-INPG-UJF, \\ BP 75, 38402 St Martin d'Hères Cédex, France
}

${ }^{d}$ Université Joseph Fourier Grenoble 1, Département de Chimie Moléculaire, UMR CNRS-5250, Institut de Chimie Moléculaire de Grenoble, FR CNRS-2607, BP 53, 38041, Grenoble Cedex 9, France

\begin{abstract}
Materiais de eletrodo de compostos poliméricos de níquel foram sintetizados a partir da redução eletroquímica de cátions ou complexos de níquel(II), incorporados por troca iônica ou por complexação, em vários tipos de filmes finos de polipirróis carboxilatos que recobriam eletrodos de carbono preparados por eletropolimerização oxidativa. A atividade eletrocatalítica e a estabilidade desses diferentes compostos foram avaliadas pela hidrogenação eletrocatalítica de cetonas e enonas em eletrólitos aquosos. Os melhores resultados foram obtidos usando-se compostos poliméricos de níquel sintetizados pela eletrorredução dos íons níquel(II) complexados em filmes de policarboxilatos, que são caracterizados por uma alta atividade catalítica e uma boa estabilidade operacional.
\end{abstract}

Nickel-polymer composite electrode materials have been synthesized using various strategies, all comprising the electrochemical reduction of nickel(II) cations or complexes, incorporated by either ion-exchange or complexation into various poly(pyrrole-carboxylate) thin films coated by oxidative electropolymerization onto carbon electrodes. The electrocatalytic activity and the stability of the different composites have been then evaluated in the course of the electrocatalytic hydrogenation of ketones and enones in aqueous electrolytes. The best results were obtained using nickel-polymer composites synthesized by electroreduction of nickel(II) ions complexed into polycarboxylate films, which are characterized by a high catalytic activity and a good operational stability.

Keywords: functionalized polypyrrole, electrodeposition, polymer-metal nanocomposite, nickel, electrocatalytic hydrogenation

\section{Introduction}

New properties are now readily accessible with nanosized metal particles, because of their unique electronic structure and their extremely large surface areas. ${ }^{1}$ These materials have emerged as an area of great current interest motivated by potential applications in chemical catalysis, energy technology, electronics, optics and magnetics. ${ }^{2-6}$ Their properties may be tuned via control of the metal particles shape, size and organization..$^{7}$ They also depend on the chemical nature of the microenvironment surrounding the particle. ${ }^{8}$ In many

\footnotetext{
*e-mail: Jean-Claude.Moutet@ujf-grenoble.fr
}

instances, to fully exploit their great potential in technological applications, it is very important to assemble the metal particles in two- and three dimensions and to endow them with good processability. This can be readily accomplished by their encapsulation in different polymers. ${ }^{9-11}$ The use of functional polymers as support for metal nanoparticles offer some exciting features via the generation of composites containing metal particles with controlled size and size distribution, thus providing a mean to influence the properties of the nanocomposite through the interaction of the metal surface with the functional groups of the polymer.

In this field, metal micro and nanoparticles dispersed in conducting polymer films are a class of promising electrode 
materials for catalytic applications. ${ }^{11-14}$ Electrochemical procedures for the synthesis of metal nanoparticles, although less common than chemical routes, have proven to be powerful and versatile means of preparing nanoparticles in a wide range of noble and transition metals. ${ }^{15}$ Electrochemical methods have also proved to be effective in incorporating metal particles in either predeposited polymers or in growing films. ${ }^{12-14}$ This is especially true in the case of electron-conducting polymers containing metal nanoparticles for electrocatalytic applications. ${ }^{16,17} \mathrm{It}$ should be emphasized that electrochemical syntheses of metal-polymer composites have essentially been reported with noble metal-based materials. ${ }^{3,14,16,17}$

In contrast, examples of electrodeposition in conducting polymers of transition metals such as copper, ${ }^{18-23}$ nickel,,$^{24-27}$ or zinc $^{28}$ are more scarce, in spite of the potential interest of transition metal-based electrode materials in electrosynthesis. ${ }^{26,29,30}$ As demonstrated in the case of the deposition of copper ${ }^{20,31}$ and cadmium $^{31}$ by direct electroreduction of metal salts onto conducting polymer film-modified electrodes, the main problems for the electrosynthesis of transition metals-polymer composites concern the poor polymer conductibility in the potential domain usually required for the reduction of metal species, and the morphology of the metal deposit obtained, i.e. at the outer polymer surface or in open pores of the polymer film coated onto a substrate material. In addition, the interaction between deposited metal and the polymer substrate is relatively weak. ${ }^{20}$

We have already demonstrated that the electrochemical reduction of anionic copper and nickel-oxalate complexes onto cationic poly(pyrrole-alkylammonium) films allows to synthesize copper ${ }^{32}$ and nickel ${ }^{33}$ based metal-polymer composites, which have been successfully used for the electrocatalytic reduction of organic substrates in aqueous electrolytes. More recently we reported the electrosynthesis of a complexing poly(pyrrole-malonic acid) electrode material allowing large amounts of transition metal ions to be accumulated. ${ }^{34-36}$ Metal particles could be dispersed in the polymer modified electrode through a ligand mediated metal ions accumulation, followed by the electrochemical reduction of the complexed cations into zerovalent metallic species. ${ }^{34}$ The electroreduction of metal complexes covalently bound to the polymer chains is expected to lead to a better dispersion of metal particles throughout the polymer matrix. Furthermore, a polymeric complexing material can work as stabilizer to prevent metal microparticles from aggregation, and could even promote specific catalytic properties. ${ }^{37}$

The present study describes the electrosynthesis and the electrocatalytic properties of nickel-polycarboxylic acid composites synthesized following two different strategies: (i) incorporation of cationic nickel(II)-ethylenediamine complexes in a functionalized polypyrrole material through a cation-exchange process, followed by an electrochemical reduction; (ii) accumulation of nickel(II) cations in complexing polypyrrole films, followed by an electrochemical reduction. The catalytic activity and the stability of the different electrode materials have been then evaluated in the course of the electrocatalytic hydrogenation of ketones and enones in aqueous media.
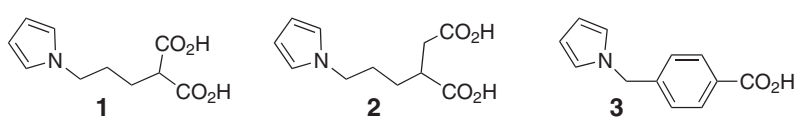

Scheme 1. Pyrrole-containing monomers used in this work.

\section{Experimental}

\section{Reagents and materials}

4-(Pyrrol-1-yl)methyl)benzoic acid $\mathbf{3}^{38}$ and (3-pyrrol1-ylpropyl)malonic acid $\mathbf{1}^{34}$ were prepared according to previously reported procedures.

(3-pyrrol-1-ylpropyl)succinic acid 2 was synthesized as follows: a solution of $n$-BuLi $\left(5 \mathrm{~mL}, 2.5 \mathrm{~mol} \mathrm{~L}^{-1}\right.$ in hexanes, $12.5 \mathrm{mmol})$ was added to $\mathrm{i}-\mathrm{Pr}_{2} \mathrm{NH}(1.8 \mathrm{~mL}$, $12.5 \mathrm{mmol}$ ) dissolved in $40 \mathrm{~mL}$ of THF at $-78^{\circ} \mathrm{C}$. The mixture was stirred at $-78^{\circ} \mathrm{C}$ for $30 \mathrm{~min}$, then mono-tertbutylsuccinate ${ }^{39}(1 \mathrm{~g}, 5.7 \mathrm{mmol})$ dissolved in $10 \mathrm{~mL}$ of THF was added dropwise. The reaction vessel was warmed to $0{ }^{\circ} \mathrm{C}$, stirred at this temperature for two hours, and cooled again to $-78{ }^{\circ} \mathrm{C}$ before $\mathrm{N}$-(3-bromopropane-1-yl)pyrrole $(1.49 \mathrm{~g}, 7.9 \mathrm{mmol})^{40}$ was added dropwise. The reaction vessel was then allowed to warm to room temperature and stirred for $24 \mathrm{~h}$, after which the reaction was quenched by adding $5 \mathrm{~mL}$ of water and the resulting reaction mixture concentrated. The solid residue was partitioned between ethylacetate $(50 \mathrm{~mL})$ and water $(20 \mathrm{~mL})$. The organic layer was then dried with anhydrous sodium sulfate, filtered and concentrated under reduced pressure. The crude mixture was purified by chromatography on silica gel to afford 2-[(3-pyrrol-1-yl)propyl]tert-butylsuccinate as an oily residue (yield 70\%). ${ }^{1} \mathrm{H} \mathrm{NMR}\left(400 \mathrm{MHz}, \mathrm{CDCl}_{3}, 298 \mathrm{~K}\right.$ ) $\delta 1.45(\mathrm{~s}, 9 \mathrm{H}) ; 1.48-1.56(\mathrm{~m}, 1 \mathrm{H}) ; 1.58-1.67(\mathrm{~m}, 1 \mathrm{H})$; $1.76-1.87(\mathrm{~m}, 2 \mathrm{H}) ; 2.37-2.46(\mathrm{~m}, 1 \mathrm{H}) ; 2.68-2.75(\mathrm{~m}, 1 \mathrm{H})$; 3.91 (t, $J 7 \mathrm{~Hz}, 2 \mathrm{H}), 6.15$ (m, 2H, pyr); 6.65 (m, 2H, pyr). ${ }^{13} \mathrm{C}$ NMR (62 $\left.\mathrm{MHz}, \mathrm{CDCl}_{3}, 298 \mathrm{~K}\right) \delta 27.9 ; 28.8 ; 35.9$; $41.3 ; 49.0 ; 81.1 ; 108.0 ; 120.3 ; 173.5 ; 178.0 . \mathrm{DCI}^{+}\left(\mathrm{NH}_{3} /\right.$ Isobutane) -MS, $m / z 282.26[\mathrm{M}+1]^{+}$.

A solution of 2-[(pyrrole-1-yl)propyl]tert-butylsuccinate $(0.3 \mathrm{~g}, 1.06 \mathrm{mmol})$ and $\mathrm{KOH}(2 \mathrm{~g}, 35.7 \mathrm{mmol})$ in absolute ethanol was refluxed for two days at $75^{\circ} \mathrm{C}$. After cooling the mixture to room temperature the solvent was removed under 
reduced pressure and the residue was partitioned between dichloromethane $(100 \mathrm{~mL})$ and water $(50 \mathrm{~mL})$. The biphasic mixture was protected from light, cooled at $0{ }^{\circ} \mathrm{C}$ with an ice bath and stirred vigorously. Aqueous $1 \mathrm{~mol} \mathrm{~L}^{-1} \mathrm{HCl}$ was then added dropwise until the $\mathrm{pH}$ reached a value between $2-3$. The organic phase was then collected and the aqueous phase was extracted with dichloromethane $(2 \times 50 \mathrm{~mL})$ and diethylether $(2 \times 50 \mathrm{~mL})$. The organic fractions were collected, dried over anhydrous sodium sulfate, filtered and the solvent was evaporated under reduced pressure to afford 2 as a light brown solid material. (yield 59\%). ${ }^{1} \mathrm{H}$ NMR $\left(250 \mathrm{MHz}, \mathrm{CD}_{3} \mathrm{CN}, 298 \mathrm{~K}\right) \delta 1.34-1.60(\mathrm{~m}, 2 \mathrm{H}), 1.68-1.80$ $(\mathrm{m}, 2 \mathrm{H}), 2.35-2.73(\mathrm{~m}, 3 \mathrm{H}), 3.85(\mathrm{t}, J 7 \mathrm{~Hz}, 2 \mathrm{H}), 6.01(\mathrm{~m}$, $2 \mathrm{H}$, pyr), 6.64 (m, 2H, pyr). ${ }^{13} \mathrm{C} \mathrm{NMR}\left(62 \mathrm{MHz}, \mathrm{CD}_{3} \mathrm{CN}\right.$, 298 K) $\delta$ 29.4; 29.6; 35.8; 41.1; 49.6; 108.6; 121.3; 173.9; 176.6. $\mathrm{EI}^{+}-\mathrm{MS}, \mathrm{m} / z, 225[\mathrm{M}]^{+}$.

The tris(ethylenediamine)nickel(II) complex was prepared by the reaction of $2.06 \mathrm{~g}(7.8 \mathrm{mmol})$ of $\mathrm{NiSO}_{4} \cdot 6 \mathrm{H}_{2} \mathrm{O}$ dissolved in $15 \mathrm{~mL}$ of water, with $2 \mathrm{~mL}$ (30 mmol) 1,2-diaminoethane. The resulting solution was filtered and concentrated. The precipitate was collected by suction filtration, washed with EtOH, and dried under vacuum. The yield was $40 \%$.

Acetonitrile (Rathburn, HPLC grade S) and tetra- $n$ butylammonium perchlorate (TBAP, Fluka puriss) for the electrochemical experiments were used as received. Nickel sulfate, succinic acid and boric acid were of reagent grade and used as received. Distilled water was obtained from an Elgastat water purification system $(5 \mathrm{M} \Omega \mathrm{cm})$.

\section{Electrodes, electrochemical cell and instrumentation}

All electrochemical experiments were carried out using an EGG PAR model 273 potentiostat equipped with an $x-y$ recorder. A standard three-electrode cell was used for analytical experiments. Potentials are referred to the $\mathrm{Ag} \mid \mathrm{AgCl}$ in $3 \mathrm{~mol} \mathrm{~L}^{-1} \mathrm{KCl}$ reference electrode in aqueous electrolytes, and to the $\mathrm{Ag} \mid \mathrm{Ag}^{+} 10^{-2} \mathrm{~mol} \mathrm{~L}^{-1}$ in $\mathrm{CH}_{3} \mathrm{CN}+0.1 \mathrm{~mol} \mathrm{~L}^{-1}$ TBAP in acetonitrile electrolyte. Glassy carbon disc electrodes $(3 \mathrm{~mm}$ diameter, from $\mathrm{CH}$ Instruments) were polished with $1-\mu \mathrm{m}$ diamond paste. For FT-IR measurements, films were grown on a $0.5 \mathrm{~cm}^{2}$ Pt foil. Spectra were recorded using a Perkin-Elmer GX spectrophotometer equipped with a variable angle specular reflectance accessory. All experiments were run at room temperature under an argon atmosphere.

\section{Preparation of the modified electrodes}

The polymer films were grown from unstirred solutions of monomers $1-3\left(4 \times 10^{-3} \mathrm{~mol} \mathrm{~L}^{-1}\right)$ in $\mathrm{CH}_{3} \mathrm{CN}$ containing $0.1 \mathrm{~mol} \mathrm{~L}^{-1} \mathrm{TBAP}$ as supporting electrolyte, by potentiostatic oxidative electropolymerization at 0.85-0.90 V vs $\mathrm{Ag} \mid \mathrm{Ag}^{+} 0.01 \mathrm{~mol} \mathrm{~L}^{-1} .{ }^{34,41}$ Polymerization experiments were controlled through the anodic charge recorded during the electrolysis. The amount of pyrrole units in the films and thus, the apparent surface coverage in complexing units $\left(\Gamma_{\mathrm{L}}, \mathrm{mol} \mathrm{cm} \mathrm{cm}^{-2}\right)$ were determined after transfer of the modified electrodes into monomer-free $\mathrm{CH}_{3} \mathrm{CN}$ electrolyte from the integration of the polypyrrole oxidation wave recorded at low scan rate $\left(10 \mathrm{~m} \mathrm{~V} \mathrm{~s}^{-1}\right)$. For electrocatalytic hydrogenations, polymer films were grown on carbon felt (RVC 2000, $65 \mathrm{mg} \mathrm{cm}^{-3}$, from Le Carbone Lorraine) electrodes $(20 \times 25 \times 4 \mathrm{~mm})$. Procedures used for the incorporation of nickel metal into the different polymeric matrices will be described in the results and discussion section.

\section{Determination of nickel loading into polycarboxylate materials}

The amount of nickel dispersed into polycarboxylate films was determined using poly3-Ni(0) materials coated on carbon felt discs (11 mm diameter, $4 \mathrm{~mm}$ thick, $\left.0.38 \mathrm{~cm}^{3}\right)$, or on indium tin oxide (ITO) coated glass slides $\left(1 \mathrm{~cm}^{2}\right)$. Samples were digested at $100-130{ }^{\circ} \mathrm{C}$ in a mixture of concentrated $\mathrm{H}_{2} \mathrm{SO}_{4}+\mathrm{HNO}_{3}$. Nickel concentrations were determined by Induction Coupled Plasma measurements performed using a Thermo Jarell Ash (IRIS) spectrometer set up with argon plasma flow at $10 \mathrm{~L} \mathrm{~h}^{-1}$, with auxiliary gas flow of $2 \mathrm{~L} \mathrm{~h}^{-1}$, and at a power of $1.55 \mathrm{~kW}$. Samples were aspired at a flow of $2.2 \mathrm{~mL} \mathrm{~min}^{-1}$ through a cyclonic nebulizer (Meinhart). Atomic emissions for Ni were determined at $221.64 \mathrm{~nm}$ and $231.60 \mathrm{~nm}$. Fresh working calibration solutions were prepared by properly diluting commercial standards with double distilled water. Calibrations within the expected range (0-50 ppm) were obtained with six equally spaced concentrations.

\section{Electrocatalytic hydrogenation procedure}

Electrocatalytic hydrogenations were carried out in a H-shaped three-compartment cell. The carbon felt electrodes modified with nickel-polymer composite films were placed in the cathodic compartment filled with $50 \mathrm{~mL}$ of a deaerated equivolumic water-methanol solution containing $0.1 \mathrm{~mol} \mathrm{~L}^{-1} \mathrm{NaCl}+0.1 \mathrm{~mol} \mathrm{~L}^{-1} \mathrm{H}_{3} \mathrm{BO}_{3}$ (initial $\mathrm{pH}$ 5.3). The potential was maintained at $-1.2 \mathrm{~V}$ for several min (hydrogen evolution). The current was then fixed at $20 \mathrm{~mA}$ and the substrate $(1 \mathrm{mmol})$ was added. The working potential stabilized at around $-1 \mathrm{~V}$ in these experimental conditions. The reaction progress was followed by periodic 
withdrawals. Samples were extracted with diethylether and analyzed by GC. The identification of products was based on GC comparison with authentic samples.

\section{Results and Discussion}

\section{Deposition of nickel in polypyrrole-malonic acid (poly1) films}

It is well established that the dianions of malonic acid and its 2-substituted derivatives form various complexes with nickel(II) cations. In particular the malonate anion forms rather stable monometallic $\mathrm{NiL}\left(\log \beta_{1}=3.2\right)$ and $\left[\mathrm{Ni}(\mathbf{L})_{2}\right]^{2-}\left(\log \beta_{2}=4.9\right)$ species $\left(\mathbf{L}=\right.$ malonate) ${ }^{42}$ The complexation ability of poly 1 towards transition metal cations such as $\mathrm{Cu}(\mathrm{II}), \mathrm{Pb}(\mathrm{II})$, $\mathrm{Cd}$ (II) and $\mathrm{Hg}$ (II) has already been demonstrated, as the precipitation of zerovalent metal particles in the polymer upon electroreduction of metal ions complexed into poly 1 films. ${ }^{3436}$

A typical cyclic voltammetry (CV) curve recorded at a carbon disc electrode in aqueous boric acid $\left(0.1 \mathrm{~mol} \mathrm{~L}^{-1}\right.$, $\mathrm{pH}$ 5.5) containing $\mathrm{NiSO}_{4}\left(1 \mathrm{mmol} \mathrm{L}^{-1}\right)$ and malonic acid $\left(5 \mathrm{mmol} \mathrm{L}^{-1}\right)$ is shown in Figure 1A. The sharp increase in the cathodic current below $-1.4 \mathrm{~V}$ is attributed to the reduction of nickel-malonate complexes leading to the precipitation of nickel on the electrode surface, concomitant with hydrogen evolution on the nickel-coated carbon electrode. It has been recently shown that malonate buffer allows efficient electrodeposition of nickel. ${ }^{43}$ Boric acid has been used as electrolyte, since it is known to improve nickel deposition. ${ }^{44}$ On the reverse scan, the large anodic wave observed at $1.6 \mathrm{~V}$ is due to nickel dissolution in the transpassivity region. ${ }^{45}$ These observations are in agreement with similar findings obtained upon studying the electroreduction of nickel(II) in the presence of oxalate anions. ${ }^{33}$

The effective coordination of nickel(II) into poly 1 films soaked for a few minutes in $0.1 \mathrm{~mol} \mathrm{~L}^{-1} \mathrm{NiSO}_{4}$ (pH 5.5) was proved by $\mathrm{CV}$ experiments carried out in clean $\mathrm{Na}_{2} \mathrm{SO}_{4}$ electrolyte containing boric acid. The poly 1 film has been over-oxidized by potentiostating the modified electrode at $1.1 \mathrm{~V}$ for $15 \mathrm{~min}$ in acetonitrile electrolyte, in order to obtain a voltammogram without the electroactivity of the polypyrrole backbone. A representative voltammogram is shown in Figure 1B. The Clpoly1-Ni(II) modified electrode displays a wave corresponding to the reduction of the complexed nickel ions associated, in the reverse scan, with an anodic nickel metal dissolution peak (Figure 1B, curve a). The dissolution of the entrapped nickel particles is achieved entirely in one $\mathrm{CV}$ cycle and the second $\mathrm{CV}$ curve does not present any anodic peak (Figure 1B, curve b). To confirm the successful deposition of nickel metal in poly1 films, C|poly1 modified electrodes have been soaked for $15 \mathrm{~min}$ in aqueous $\mathrm{NiSO}_{4}(\mathrm{pH} 5.5)$, thoroughly rinsed and reduced at $-1.4 \mathrm{~V}$ in $0.1 \mathrm{~mol} \mathrm{~L}^{-1} \mathrm{Na}_{2} \mathrm{SO}_{4}$ containing $0.1 \mathrm{~mol} \mathrm{~L}^{-1} \mathrm{H}_{3} \mathrm{BO}_{3}$. Then the anodic nickel metal dissolution was studied by $\mathrm{CV}$ experiments carried out in clean $\mathrm{Na}_{2} \mathrm{SO}_{4}$ electrolyte. Typical curves are shown in Figure 1C. Under these experimental conditions $\left(\Gamma_{\mathrm{L}}=9.5 \times 10^{-7} \mathrm{~mol} \mathrm{~cm}^{-2}\right.$, scan rate $0.1 \mathrm{~V} \mathrm{~s}^{-1}$ ) the total dissolution of the metal requires two CV scans (Figure 1C, curves a-c).

The coordination of nickel(II) into poly1 films has been confirmed by FT-IR experiments, using films grown on a Pt foil (see the experimental section). The infrared spectrum of poly 1 is characterized by two bands at 1733 and $1718 \mathrm{~cm}^{-1}$ (Figure 2A, curve a) assigned to the $\mathrm{C}=\mathrm{O}$ stretching vibration of the malonic acid moieties. After immersion or the poly 1 film for a few minutes in $10^{-2} \mathrm{~mol} \mathrm{~L}^{-1} \mathrm{NiSO}_{4}$ (pH 5.5) a new broad band appears around $1585 \mathrm{~cm}^{-1}$ attributed to the $\mathrm{OCO}$ vibrations modes in nickel-malonate complexes (Figure 2A, curve b). A similar band was observed at $1578 \mathrm{~cm}^{-1}$ in the spectrum of a poly[Ni(II)-dicarboxylate] film. ${ }^{46}$ Full complexation of poly1 was readily obtained when the concentration of by $\mathrm{Ni}^{2+}$ cations in the accumulation solution was increased up to $10^{-1} \mathrm{~mol} \mathrm{~L}^{-1}$. The absorption bands corresponding to the free malonic acid groups are no longer observed and the spectrum present an intense band at $1570 \mathrm{~cm}^{-1}$ attributed to nickel-malonate complexes (Figure 2A, curve c). These results show that the efficient complexation of nickel in poly 1 films requires the use of a rather high concentration of nickel cations $\left(10^{-1} \mathrm{~mol} \mathrm{~L}^{-1}\right)$ and a weakly acidic media ( $\mathrm{pH}$ 5.5).

Deposition of nickel in polypyrrole-succinic acid (poly2) films

Polysuccinic acid-nickel composite electrode materials have been synthesized following the same procedure, as described above for polymalonic acid-based composites. The electrochemical behavior of the pyrrole-succinic acid (monomer 2; scheme 1) in $\mathrm{CH}_{3} \mathrm{CN}+0.1 \mathrm{~mol} \mathrm{~L}^{-1}$ TBAP is very similar to that found for monomer $\mathbf{1}$. CV curves exhibit the regular irreversible oxidation peak $\left(E_{\mathrm{pa}} c a .1 \mathrm{~V} v s \mathrm{Ag} \mid \mathrm{Ag}^{+} 0.01 \mathrm{~mol} \mathrm{~L}^{-1}\right)$ systematically observed with $\mathrm{N}$-substituted pyrroles, and an irreversible reduction peak $\left(E_{\mathrm{pc}} c a .-1.2 \mathrm{~V}\right.$ on $\left.\mathrm{Pt}\right)$ attributed to the reduction of the protons of the carboxylic acid groups. Poly2 films can be grown on platinum and carbon electrodes by cycling over the $-0.4 \mathrm{~V}$ to $0.9 \mathrm{~V}$ potential range, or by controlledpotential oxidation at $0.85 \mathrm{~V}\left(\mathrm{Ag} \mid \mathrm{Ag}^{+} 0.01 \mathrm{~mol} \mathrm{~L}^{-1}\right)$. Films with apparent surface coverage $\left(\Gamma_{\mathrm{L}}\right)$ around $10^{-7} \mathrm{~mol} \mathrm{~cm}^{-2}$ could be obtained with polymerization yields above $50 \%$.

The complexation ability of succinic acid towards transition metal cations is weaker than that of malonic acid. In particular, it is known that succinic acid forms with nickel(II) a NiL complex characterized by a lower complexation constant $\left(\log \beta_{1}=1.6\right)$ than the corresponding 


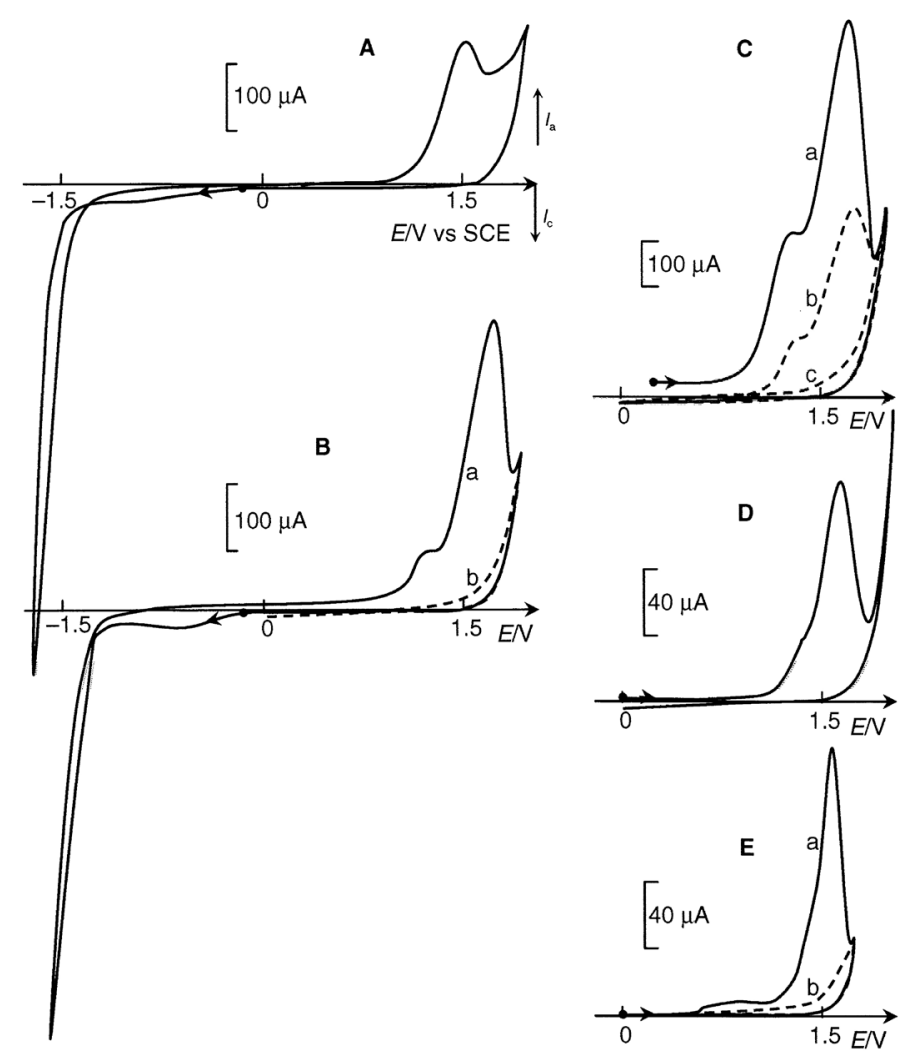

Figure 1. (A) Cyclic voltammetry curve recorded at a carbon disc electrode (3 mm diameter) in $0.1 \mathrm{~mol} \mathrm{~L}^{-1} \mathrm{H}_{3} \mathrm{BO}_{3}$ ( $\left.\mathrm{pH} 5.5\right)$ containing $1 \mathrm{mmol} \mathrm{L} \mathrm{L}^{-1}$ $\mathrm{NiSO}_{4}$ and $5 \mathrm{mmol} \mathrm{L}{ }^{-1}$ malonic acid; scan rate $=0.1 \mathrm{~V} \mathrm{~s}^{-1}$. (B) Cyclic voltammograms in $0.1 \mathrm{~mol} \mathrm{~L}^{-1} \mathrm{Na}_{2} \mathrm{SO}_{4}$ (pH 5.5) at a Clpoly1 modified electrode $\left(3 \mathrm{~mm}\right.$ in diameter, $\left(\Gamma_{\mathrm{L}}=2.5 \times 10^{-7} \mathrm{~mol} \mathrm{~cm}^{-2}\right)$ that has been immersed for $15 \mathrm{~min}$ in $0.1 \mathrm{~mol} \mathrm{~L}^{-1} \mathrm{NiSO}_{4}$, $\mathrm{pH} 5.5$; curve a: first scan $0 \mathrm{~V} \rightarrow-1.6 \mathrm{~V} \rightarrow+1.8 \mathrm{~V}$; curve $\mathrm{b}$ (dashed line): second scan restricted to the range 0 to $+1.8 \mathrm{~V}$; scan rate $=0.1 \mathrm{~V} \mathrm{~s}^{-1}$. (C) Anodic stripping wave in $0.1 \mathrm{~mol} \mathrm{~L}^{-1} \mathrm{Na}_{2} \mathrm{SO}_{4}+0.1 \mathrm{~mol} \mathrm{~L}^{-1}$ $\mathrm{H}_{3} \mathrm{BO}_{3}$ for nickel deposited in a poly 1 film $\left(\Gamma_{\mathrm{L}}=9.5 \times 10^{-7} \mathrm{~mol} \mathrm{~cm}{ }^{-2}\right)$ soaked for $15 \mathrm{~min}$ in $0.1 \mathrm{~mol} \mathrm{~L}^{-1} \mathrm{NiSO}_{4}(\mathrm{pH} 5.5)$, then reduced at $-1.4 \mathrm{~V}$ in clean $0.1 \mathrm{~mol} \mathrm{~L}^{-1} \mathrm{Na}_{2} \mathrm{SO}_{4}+0.1 \mathrm{~mol} \mathrm{~L}^{-1} \mathrm{H}_{3} \mathrm{BO}_{3}\left(\mathrm{pH} 5.3\right.$ ); curve a: $1^{\text {st }}$ scan; curve b: $2^{\text {nd }}$ scan; curve c: $3^{\text {rd }}$ scan; scan rate $=0.1 \mathrm{~V} \mathrm{~s}^{-1}$. (D) Anodic stripping wave in $0.1 \mathrm{~mol} \mathrm{~L}^{-1} \mathrm{Na}_{2} \mathrm{SO}_{4}+0.1 \mathrm{~mol} \mathrm{~L}^{-1} \mathrm{H}_{3} \mathrm{BO}_{3}$ for nickel deposited in a poly2 film $\left(\Gamma_{\mathrm{L}}=10^{-7} \mathrm{~mol} \mathrm{~cm}^{-2}\right)$ soaked for $30 \mathrm{~min}$ in $0.1 \mathrm{~mol} \mathrm{~L}^{-1} \mathrm{NiSO}_{4}\left(\mathrm{pH}_{5.5}\right)$, then reduced at $-1.4 \mathrm{~V}$ in clean $0.1 \mathrm{~mol} \mathrm{~L}^{-1} \mathrm{Na}_{2} \mathrm{SO}_{4}+0.1 \mathrm{~mol} \mathrm{~L}^{-1} \mathrm{H}_{3} \mathrm{BO}_{3}, \mathrm{pH} 5.2$; scan rate $=0.01 \mathrm{~V} \mathrm{~s}^{-1}$. (E) Anodic stripping wave in $0.1 \mathrm{~mol} \mathrm{~L}^{-1} \mathrm{Na}_{2} \mathrm{SO}_{4}$ for nickel metal deposited in a poly 3 film $\left(\Gamma_{\mathrm{L}}=1.5 \times 10^{-8} \mathrm{~mol} \mathrm{~cm}^{-2}\right)$ soaked for $30 \mathrm{~min}$ in $0.1 \mathrm{~mol} \mathrm{~L}^{-1} \mathrm{NiSO}_{4}(\mathrm{pH} 5.7)$, then reduced at $-1.4 \mathrm{~V}$ in clean $0.1 \mathrm{~mol} \mathrm{~L}^{-1} \mathrm{Na}_{2} \mathrm{SO}_{4}, \mathrm{pH} 5.4 ;$ scan rate $=0.01 \mathrm{~V} \mathrm{~s}^{-1}$; curve a: $1^{\text {st }}$ scan; curve b: $2^{\text {nd }}$ scan.

nickel-malonic acid complex $\left(\log \beta_{1}=3.2\right) \cdot{ }^{42}$ However, just as for C|poly1 film modified electrodes, the effective complexation of nickel(II) cations and the electroreductive deposition of nickel metal in poly 2 films has been demonstrated following the same basic procedure. Clpoly 2 modified electrodes have been soaked in aqueous $\mathrm{NiSO}_{4}$ $\left(0.1 \mathrm{~mol} \mathrm{~L}^{-1}, \mathrm{pH} 5.5\right)$, thoroughly rinsed and reduced at $-1.4 \mathrm{~V}$ in $0.1 \mathrm{~mol} \mathrm{~L}^{-1} \mathrm{Na}_{2} \mathrm{SO}_{4}$ containing $0.1 \mathrm{~mol} \mathrm{~L}^{-1} \mathrm{H}_{3} \mathrm{BO}_{3}$. Then the anodic nickel metal dissolution was studied by $\mathrm{CV}$ in clean $\mathrm{Na}_{2} \mathrm{SO}_{4}+\mathrm{H}_{3} \mathrm{BO}_{3}$ electrolyte. A typical curve, characterized by a strong nickel anodic stripping peak at $1.5 \mathrm{~V}$ is shown in Figure 1D. It confirms the successful deposition of nickel metal in poly 2 films using the complexation-electroreduction procedure.

\section{Deposition of nickel in polypyrrole-benzoic acid (poly3) films}

The electrosynthesis of polypyrrole-benzoic acid (poly3) thin films, along with its cation-exchange properties, have already been reported. ${ }^{41}$ The $\mathrm{p} K_{\mathrm{a}}$ of poly 3 has been found at 5.2. Its exchange capacity has been estimated at 4.5 molar equiv. $\mathrm{kg}^{-1},{ }^{41}$ which is comparable to common cation-exchange resins. The effective complexation of nickel(II) into poly 3 films has been evidenced by FT-IR experiments. The infrared spectrum of a poly 3 film is characterized by a band at $1713 \mathrm{~cm}^{-1}$ (Figure 2B, curve a) assigned to the $\mathrm{C}=\mathrm{O}$ stretching vibration of the benzoic acid moieties. After immersion or the poly3 film in $0.1 \mathrm{~mol} \mathrm{~L}^{-1}$ $\mathrm{NiSO}_{4}, \mathrm{pH} 7$, this band is no longer observed and the spectrum present two new bands at 1592 and $1540 \mathrm{~cm}^{-1}$ attributed to nickel-carboxylate complexes (Figure 2B, curve b).

Firstly, nickel metal was dispersed in thin poly 3 films by complexation and/or ion-exchange of nickel(II) cations, followed by an electrochemical reduction. The electroreductive deposition of $\mathrm{Ni}(0)$ in poly 3 films was proved as follows. C|poly 3 modified electrodes have been soaked for $30 \mathrm{~min}$ in aqueous $\mathrm{NiSO}_{4}\left(0.1 \mathrm{~mol} \mathrm{~L}^{-1}, \mathrm{pH} 5.7\right)$, 

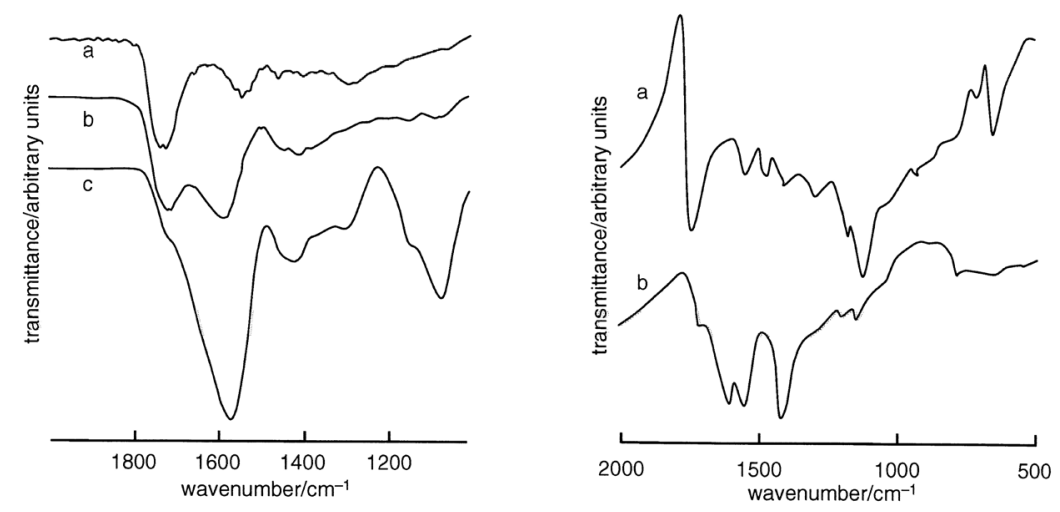

Figure 2. (A) FT-IR spectra of a poly 1 film coated on Pt, before (curve a) and after soaking for 10 min in $10 \mathrm{mmol} \mathrm{L}^{-1}$ (curve b) and $0.1 \mathrm{~mol} \mathrm{~L}^{-1}$ (curve c) $\mathrm{NiSO}_{4}\left(\mathrm{pH}\right.$ 5.5). (B) FT-IR spectra of a poly3 film before (curve a) and after (curve b) soaking in $0.1 \mathrm{~mol} \mathrm{~L}^{-1} \mathrm{NiSO}_{4}(\mathrm{pH} 7$ ).

thoroughly rinsed and reduced at $-1.4 \mathrm{~V}$ in $0.1 \mathrm{~mol} \mathrm{~L}^{-1}$ $\mathrm{Na}_{2} \mathrm{SO}_{4}$. Then the anodic nickel metal dissolution was studied by $\mathrm{CV}$ in clean $\mathrm{Na}_{2} \mathrm{SO}_{4}$ electrolyte. A typical $\mathrm{CV}$ curve, characterized by an intense nickel anodic stripping peak at $1.5 \mathrm{~V}$, is shown in figure $1 \mathrm{E}$ (curve a). The total dissolution of the metal is achieved in one CV scan (scan rate $10 \mathrm{mV} \mathrm{s}^{-1}$ ), and the second $\mathrm{CV}$ curve does not show any anodic peaks (Figure 1E, curve b). As judged by the intensity of the stripping peaks in different experiments, we found that the incorporation of nickel in poly 3 reached a maximum when the $\mathrm{pH}$ of the accumulation solution containing nickel(II) cations is around 6 .

A nickel-polymer composite electrode material has also been synthesized by incorporation, by ion-exchange, of cationic nickel-ethylenediamine complexes in deprotonated poly 3 films, followed by the electrochemical reduction of these complexes to nickel metal. The literature data concerning the electroreduction of nickel(II) ethylenediamine complexes are scarce and controversial. ${ }^{47}$ However, it has been shown that ethylenediamine can dramatically increase nickel electrodeposition. ${ }^{48}$

Ethylenediamine (denoted en) and nickel(II) form rather stable species as $\mathrm{Ni}(\mathrm{en})^{2+}\left(\log \beta_{1}=7.4\right), \mathrm{Ni}(\mathrm{en})_{2}{ }^{2+}$ $\left(\log \beta_{2}=13.5\right)$, and $\mathrm{Ni}(\mathrm{en})_{3}{ }^{2+}\left(\log \beta_{3}=17.7\right)$ complexes. ${ }^{42}$ The efficiency of the complexation process depends on the $\mathrm{pH}$, since protonation of ethylenediamine and precipitation of nickel hydroxide $\left(\log \beta_{\mathrm{OH}}=4.6\right)$ can compete with the formation of Ni-en complexes. With the help of these stability constants determined with a method similar to that already used for other chelate complexes of nickel(II), ${ }^{33}$ one can calculate the distribution diagram for the nickelethylenediamine system which shows that the $\mathrm{Ni}(\mathrm{en})_{3}{ }^{2+}$ complex predominate in solution for $\mathrm{pH}$ values around 7 .

A typical voltammogram obtained with tris(ethylenediamine)nickel(II) $\left(1 \mathrm{mmol} \mathrm{L}^{-1}\right)$ in $\mathrm{Na}_{2} \mathrm{SO}_{4}$ electrolyte containing boric acid (pH 7) is shown in Figure 3A. The reduction of the complex is characterized by a sharp

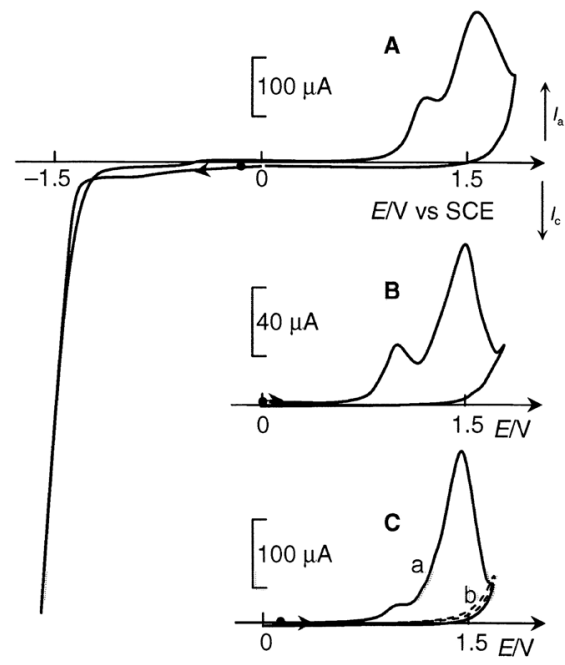

Figure 3. (A) Cyclic voltammetry curve for $1 \mathrm{mmol} \mathrm{L}^{-1} \mathrm{Ni}(\mathrm{en}){ }_{3}{ }_{3}^{2+}$ recorded at a carbon disc electrode ( $3 \mathrm{~mm}$ diameter) in $0.1 \mathrm{~mol} \mathrm{~L}^{-1} \mathrm{Na}_{2} \mathrm{SO}_{4}+$ $0.1 \mathrm{~mol} \mathrm{~L}^{-1} \mathrm{H}_{3} \mathrm{BO}_{3}(\mathrm{pH} 7)$; scan rate $=0.1 \mathrm{~V} \mathrm{~s}^{-1}$. (B) Nickel anodic stripping wave in clean $0.1 \mathrm{~mol} \mathrm{~L}^{-1} \mathrm{Na}_{2} \mathrm{SO}_{4}$ electrolyte, following metal deposition by reduction at $-1.5 \mathrm{~V}$ (charge passed $6 \mathrm{mC}$ ) in the same solution as in $3 \mathrm{~A}$; scan rate $=0.01 \mathrm{~V} \mathrm{~s}^{-1}$. (C) Nickel metal anodic stripping wave in clean $0.1 \mathrm{~mol} \mathrm{~L}^{-1} \mathrm{Na}_{2} \mathrm{SO}_{4}$ for nickel deposited in a poly 3 film $\left(\Gamma_{\mathrm{L}}=1.3 \times\right.$ $10^{-7} \mathrm{~mol} \mathrm{~cm}^{-2}$ ) soaked for $30 \mathrm{~min}$ in $10 \mathrm{mmol} \mathrm{L}^{-1} \mathrm{Ni}(\mathrm{en})_{3}^{2+}$, then rinsed and reduced at $-1.4 \mathrm{~V}$ in clean $\mathrm{Na}_{2} \mathrm{SO}_{4}+\mathrm{H}_{3} \mathrm{BO}_{3}$ electrolyte; curve a: $1^{\text {st }}$ scan; curve b: $2^{\text {nd }}$ scan; scan rate $=0.01 \mathrm{~V} \mathrm{~s}^{-1}$.

increase in the cathodic current below $-1.4 \mathrm{~V}$, which can be attributed to nickel deposition concomitant with hydrogen evolution on nickel. On the reverse scan, the strong anodic peak at $1.6 \mathrm{~V}$ is attributed to nickel dissolution in the transpassivity region..$^{45}$ Larger stripping currents were observed when boric acid is present in the electrolyte. The electrodeposition of nickel onto the carbon electrode surface was performed by reduction at $-1.5 \mathrm{~V}$ in a solution of $\mathrm{Ni}(\mathrm{en})_{3}{ }_{3}^{2+}\left(1 \mathrm{mmol} \mathrm{L}^{-1}\right)$ in $0.1 \mathrm{~mol} \mathrm{~L}^{-1} \mathrm{Na}_{2} \mathrm{SO}_{4}+0.1 \mathrm{~mol} \mathrm{~L}^{-1}$ $\mathrm{H}_{3} \mathrm{BO}_{3}(\mathrm{pH}$ 7). The amount of electroprecipitated metal was estimated from the charge recorded under the anodic stripping wave. A typical result is presented in Figure 3B. Comparison with the charge consumed during the reduction at $-1.5 \mathrm{~V}$ of the nickel-ethylenediamine complex to nickel 
metal suggests that this process is not quantitative. For example, stripping charges of $5.1 \mathrm{mC}$ (Figure $3 \mathrm{~B}$ ) and $6.0 \mathrm{mC}$ were measured when the deposition charges were $6 \mathrm{mC}$ and $12 \mathrm{mC}$, respectively. The difference may be explained as a result of the cathodic charge being partly consumed for hydrogen evolution.

Nickel metal was precipitated into poly 3 films via incorporation, by ion-exchange, of cationic Ni-en complexes, followed by their electrochemical reduction. Typically, a Clpoly 3 electrode was soaked for $30 \mathrm{~min}$ in a $10 \mathrm{mmol} \mathrm{L}{ }^{-1} \mathrm{Ni}(\mathrm{en})_{3}^{2+}$ solution, thoroughly rinsed with water, then reduced at $-1.4 \mathrm{~V}$ in $0.1 \mathrm{~mol} \mathrm{~L}^{-1} \mathrm{Na}_{2} \mathrm{SO}_{4}+$ $0.1 \mathrm{~mol} \mathrm{~L}^{-1} \mathrm{H}_{3} \mathrm{BO}_{3}$. The effective precipitation of nickel metal into the polymer was demonstrated from anodic stripping experiments. Figure 3C (curve a) shows a representative nickel stripping wave recorded in clean $\mathrm{Na}_{2} \mathrm{SO}_{4}$ electrolyte. In these experimental conditions, total dissolution of the metal is achieved in a single CV scan (scan rate $10 \mathrm{mV} \mathrm{s}^{-1}$ ), and the second $\mathrm{CV}$ curve does not show any anodic peaks (Figure 3C, curve b).

\section{Estimation of nickel concentration into polymer films}

Attempts have been made to estimate the amount of nickel electrodeposited in polymer films from the charge involved in the nickel anodic stripping. We found however that the incorporation ratios (defined as the amount of incorporated nickel on the amount of carboxylic acid sites in the film) measured this way were well over $100 \%$ (up to $1000 \%$ ). Such over-estimation of the metal loading is not surprising since the charge consumed at the high potential value required to achieve metal stripping, most likely includes other contributions such as from the irreversible oxidation of the carboxylate groups grafted on the polymer, and the over-oxidation of the polypyrrole matrix.

Additional experiments were conducted to obtain a better estimation of the nickel loading into the polycarboxylate films. For this purpose nickel was precipitated in poly $\mathbf{3}$ films coated onto carbon felt or indium tin oxide (ITO) electrodes, by complexation of nickel(II) cations followed by their electroreduction. After digestion of the samples in boiling $\mathrm{H}_{2} \mathrm{SO}_{4}+\mathrm{HNO}_{3}$, nickel concentrations were determined by ICP measurements (see experimental).

Firstly, three poly 3 films were grown on ITO electrodes (area $c a .1 \mathrm{~cm}^{2}$ ) in a $8 \times 10^{-3} \mathrm{~mol} \mathrm{~L}^{-1}$ solution of monomer 3 in $\mathrm{CH}_{3} \mathrm{CN}$ electrolyte, by oxidative electropolymerization at $0.85 \mathrm{~V}$ (charge passed $60 \mathrm{mC}$; polymerization yields were in the 85 to $95 \%$ range). Nickel was precipitated in the polymer films using the experimental conditions previously described above $\left(0.1 \mathrm{~mol} \mathrm{~L}^{-1} \mathrm{NiSO}_{4}, \mathrm{pH} 5.7\right)$. The amount of carboxylic acid groups contained in the films, determined from the integration of the charge under the polypyrrole oxidation wave, was in the 0.22 to $0.26 \mu \mathrm{mol}$ range. The amounts of nickel in the poly 3 films, determined from ICP measurements, were in the 9 to $23 \mu \mathrm{g}$ range, i.e. 0.15 to $0.39 \mu \mathrm{mol}$. In spite of the rather scattered values found, these results show that the nickel incorporation ratio in poly 3 films is surprisingly high, i.e. 150 to $300 \%$, taking into account that to the maximum one $\mathrm{Ni}^{2+}$ cation can be bound to two carboxylate moieties in the polymer during the accumulation step. Since the polymerization yields were rather high (85-95\%) in these experimental conditions, one can reasonably assume that the conductivity of the polypyrrole films synthesized in these experimental conditions is important. Therefore the nickel incorporation ratios found over $100 \%$ cannot be explained by an underestimation of the amount of pyrrole units, and thus of the amount of carboxylic acid groups in the films, due to a wrong calculation from the integration of the polypyrrole oxidation wave. The high nickel incorporation ratios could thus be due to the formation in the polymer of 1:1 Ni-carboxylate complexes. Moreover, in addition to strong ion binding with the polycarboxylate material, binding could also exist between the nickel cations and the nitrogen atoms from pyrrole groups, possibly leading to the formation of molecular complexes. Additional interactions between transition metal cations and nitrogen atoms have been assumed in the case of carboxylic acid-based copolymer containing nitrogenous functional groups. ${ }^{49}$ Finally cation- $\pi$ interactions, which are recognized to be among the strongest of noncovalent binding forces, ${ }^{50}$ could be responsible in part of additional interactions between nickel cations and the polypyrrolic matrice, and thus to increased nickel incorporation ratios.

Similar experiments have been conducted using a series of Ni-poly3 samples coated onto carbon felt disc electrodes (11 $\mathrm{mm}$ diameter, $4 \mathrm{~mm}$ thick) in the same experimental conditions as above. Using polymerization charges of charge of 1 or $2 \mathrm{C}$, film containing between 4.9 and $9.4 \mu \mathrm{mol}$ of carboxylic acid groups have been obtained. After precipitation of nickel in these films, followed by digestion of the samples in boiling acids, ICP measurements have shown that the amount of nickel varied from 1.4 to $3.8 \mu \mathrm{mol}$ (around 0.08 to $0.22 \mathrm{mg}$ ) per $\mu \mathrm{mol}$ of carboxylic acid units. In a separate experiment carried out with a sample in which no nickel has not been incorporated, we found that the amount of nickel in the solution after digestion of the sample was negligible, demonstrating that the carbon felt was not contaminated by nickel species. These results show that the nickel incorporation ratio in poly 3 films coated on carbon felt is more than twice (280 to $760 \%$ ) what was measured in Ni-polymer composites 
coated on ITO electrodes. It is well established that carbon materials, including carbon fibers, bear some reasonable population of carboxylic acid groups on their surfaces. ${ }^{51}$ These additional carboxylate sites could be responsible for an increased metal ions binding capacity of the polymercoated on carbon felt material.

Although limited to the study of Ni-poly 3 composites, these results served to roughly estimate the nickel loading (typically 20 to $40 \mathrm{mg}$ ) in the different large size nickelpolymer film modified carbon felt electrodes, used in the course of the electrocatalytic hydrogenation experiments described in the following section.

\section{Electrocatalytic hydrogenation at the different modified electrodes}

\section{ECH at Ni-polyl cathodes}

The electrocatalytic hydrogenation $(\mathrm{ECH})$ of 2-cyclohexenone to cyclohexanone and cyclohexanol was chosen to estimate the catalytic activity of the poly1-nickel electrode material. The results obtained in the course of a series of experiments conducted at different C|poly1$\mathrm{Ni}(0)$ cathodes are summarized in Table 1. Electrocatalytic hydrogenations $(\mathrm{ECH})$ were performed in water-methanol solutions containing 2-cyclohexenone (1 mmol), in the conditions developed by Lessard and co-workers ${ }^{52}$ for reductions with Raney nickel-based electrodes (see experimental).

A carbon felt electrode modified with a poly 1 film $\left(2.5 \times 10^{-5} \mathrm{~mol}\right.$ of malonic acid units) was firstly soaked for $30 \mathrm{~min}$ in a $0.01 \mathrm{~mol} \mathrm{~L}^{-1} \mathrm{NiSO}_{4}$ aqueous solution, then reduced at $-1.4 \mathrm{~V}$ in clean $0.1 \mathrm{~mol} \mathrm{~L}^{-1} \mathrm{Na}_{2} \mathrm{SO}_{4}+0.1 \mathrm{~mol} \mathrm{~L}^{-1}$ $\mathrm{H}_{3} \mathrm{BO}_{3}$ electrolyte. In this case, $\mathrm{pHs}$ of the accumulation and reduction solutions were adjusted to 3 by adding diluted sulfuric acid. The complexation-electroreduction procedure was repeated once to increase nickel loading in the polymer film affording electrode $\mathrm{A}$, which was then used in the ECH of 2-cyclohexenone (Table 1, entry 1).

As expected with a nickel-based cathode, ${ }^{53}$ the carbon-carbon double bond of the conjugated enone was more easily hydrogenated than the carbonyl group to give cyclohexanone, and the presence of 2-cyclohexenol was not detected in the reaction mixture. However cyclohexanone could be further reduced and a small amount of cyclohexanol (8\%) was obtained after the consumption of 4 electrons per molecule of substrate (entry 1).

A significant improvement of the catalytic activity was observed with cathode B, prepared by increasing the amount of nickel loading in electrode A upon repeating twice the metal deposition procedure. Cathode B was then used in a series of ECH experiments (Table 1, entries 2-7). The
Table 1. ECH of 2-cyclohexenone at C|poly1-Ni(0) cathodes ${ }^{\mathrm{a}}$

\begin{tabular}{|c|c|c|c|c|}
\hline Entry & Cathode $^{\mathrm{b}}$ & Products & $\begin{array}{c}\text { Product } \\
\text { yield }^{c} / \%\end{array}$ & $\begin{array}{r}\text { Total current } \\
\text { efficiency } / \%\end{array}$ \\
\hline 1 & $\mathrm{~A}^{\mathrm{e}}\left(1^{\mathrm{st}} \mathrm{ECH}\right)$ & $\begin{array}{l}\text { cyclohexanone } \\
\text { cyclohexanol }\end{array}$ & $\begin{array}{c}55 \\
8\end{array}$ & 35 \\
\hline 2 & $\mathrm{~B}^{\mathrm{f}}\left(1^{\mathrm{st}} \mathrm{ECH}\right)$ & $\begin{array}{l}\text { cyclohexanone } \\
\text { cyclohexanol }\end{array}$ & $\begin{array}{l}35 \\
45\end{array}$ & 62 \\
\hline 3 & $\mathrm{~B}^{\mathrm{f}}\left(2^{\text {nd }} \mathrm{ECH}\right)$ & $\begin{array}{l}\text { cyclohexanone } \\
\text { cyclohexanol }\end{array}$ & $\begin{array}{l}29 \\
52\end{array}$ & 66 \\
\hline 4 & $\mathrm{~B}^{\mathrm{f}}\left(3^{\mathrm{rd}} \mathrm{ECH}\right)$ & $\begin{array}{l}\text { cyclohexanone } \\
\text { cyclohexanol }\end{array}$ & $\begin{array}{l}37 \\
37\end{array}$ & 55 \\
\hline 5 & $\mathrm{~B}^{\mathrm{f}}\left(4^{\text {th }} \mathrm{ECH}\right)$ & $\begin{array}{l}\text { cyclohexanone } \\
\text { cyclohexanol }\end{array}$ & $\begin{array}{l}36 \\
39\end{array}$ & 57 \\
\hline 6 & $\mathrm{~B}^{\mathrm{f}}\left(5^{\text {th }} \mathrm{ECH}\right)$ & $\begin{array}{l}\text { cyclohexanone } \\
\text { cyclohexanol }\end{array}$ & $\begin{array}{l}37 \\
39\end{array}$ & 57 \\
\hline 7 & $\mathrm{~B}^{\mathrm{f}}\left(6^{\text {th }} \mathrm{ECH}\right)$ & $\begin{array}{l}\text { cyclohexanone } \\
\text { cyclohexanol }\end{array}$ & $\begin{array}{l}64 \\
16\end{array}$ & 48 \\
\hline 8 & $\mathrm{C}^{\mathrm{g}}\left(2^{\text {nd }} \mathrm{ECH}\right)$ & $\begin{array}{l}\text { cyclohexanone } \\
\text { cyclohexanol }\end{array}$ & $\begin{array}{l}33 \\
53\end{array}$ & 69 \\
\hline
\end{tabular}

${ }^{\mathrm{a}}$ Carried out in $50 \mathrm{~mL}$ of water-methanol equimolar mixtures containing $0.1 \mathrm{~mol} \mathrm{~L}^{-1} \mathrm{NaCl}+0.1 \mathrm{~mol} \mathrm{~L}^{-1} \mathrm{H}_{3} \mathrm{BO}_{3}$ (initial $\mathrm{pH} 5.3$ ) and $1 \mathrm{mmol}$ of cyclohexenone; electrolysis current $20 \mathrm{~mA}\left(-0.9 \mathrm{~V}<E_{\text {app }}<-1.0 \mathrm{~V}\right)$. ${ }^{b} 20 \times 25 \times 4 \mathrm{~mm}$ modified carbon felt electrodes containing ca. $2.5 \times 10^{-5} \mathrm{~mol}$ of malonic acid units. ${ }^{\mathrm{G}} \mathrm{GC}$ yield, measured after the consumption of 4 electrons per molecule of 2 -cyclohexenone. ${ }^{\mathrm{d}}$ Calculated taking into account that reduction of 2-cyclohexenone to cyclohexanone and cyclohexanol requires 2 and 4 electrons, respectively. ${ }^{\mathrm{e} N i c k e l}$ deposition by complexation for $30 \mathrm{~min}$ in $0.01 \mathrm{~mol} \mathrm{~L}^{-1} \mathrm{NiSO}_{4}(\mathrm{pH} \mathrm{3})$, then reduction at $-1.4 \mathrm{~V}$ in clean $0.1 \mathrm{~mol} \mathrm{~L}^{-1} \mathrm{Na}_{2} \mathrm{SO}_{4}+0.1 \mathrm{~mol} \mathrm{~L}^{-1} \mathrm{H}_{3} \mathrm{BO}_{3}$ $(\mathrm{pH} 3)$; the nickel deposition procedure was performed twice. ${ }^{\mathrm{f}}$ Electrode $\mathrm{B}$ is electrode $\mathrm{A}$ in which two additional incorporations of $\mathrm{Ni}(0)$ has been performed in the same conditions. ${ }^{g}$ Electrode $\mathrm{C}$ was prepared as electrode $\mathrm{A}$ in solutions of $\mathrm{pH} 5$, and using a higher concentration of $\mathrm{Ni}^{2+}$ $\left(0.1 \mathrm{~mol} \mathrm{~L}^{-1}\right)$ in the accumulation solution.

increase of nickel loading led to a significant improvement in the total current efficiency, calculated at a given charge of $4 \mathrm{~F} \mathrm{~mol}^{-1}$ and setting the electrolysis current at $20 \mathrm{~mA}$, from $35 \%$ (electrode A; entry 1 ) to $55-66 \%$ (electrode B; entries 2-6). Furthermore, with electrode B the cyclohexanol yield was increased up to $52 \%$ (Table 1, entry 3 ).

An important feature of the C|poly1-Ni(0) modified electrode is its rather good operational stability, which was tested during the hydrogenation of several samples of 2-cyclohexanone on the cathode B (Table 1, entries 2-7). The current efficiency remained almost the same (current yields ranging from 55\% to 66\%) during the first five successive ECHs (entries 2-6), but a significant decrease in the catalytic activity was observed from the $6^{\text {th }}$ electrolysis. In this last experiment, the total current yield remained rather good (48\%), but the yield of cyclohexanol decreased down to $16 \%$ (Table 1, entry 7; measured after the consumption of 4 electrons per molecule of substrate), showing that the cathode has lost some catalytic activity after 6 electrolyses. 
FT-IR experiments have shown that an optimized complexation of nickel in poly 1 films was achieved at high nickel concentration $\left(0.1 \mathrm{~mol} \mathrm{~L}^{-1}\right)$ and a weakly acidic media (pH 5.5). An ECH experiment has confirmed that these accumulation conditions allowed obtaining a more efficient incorporation of nickel metal in poly1 films. As a matter of fact, the catalytic efficiency of a cathode synthesized in these experimental conditions, using only two accumulation-electroreduction steps (electrode C, entry 8), turned out to be slightly better than that of electrode $\mathbf{B}$ prepared using a $0.01 \mathrm{~mol} \mathrm{~L}^{-1} \mathrm{NiSO}_{4}$ solution of $\mathrm{pH} 3$ and four accumulation-electroreduction procedures. Very similar current efficiency and yields were obtained with these different cathodes, as shown by the comparison of the results summarized in entry $3\left(2^{\text {nd }} \mathrm{ECH}\right.$ onto electrode B) and entry 8 ( $2^{\text {nd }} \mathrm{ECH}$ onto electrode $\left.\mathbf{C}\right)$.

Comparison with results reported in the literature for the hydrogenation in aqueous electrolytes of 2-cyclohexenone shows that the catalytic activity of poly $1-\mathrm{Ni}(0)$ modified electrodes compare well with that of other nickel-based electrode materials, ${ }^{33,52,53}$ in spite of the rather small amount of nickel contained in the polymer films. As a matter of fact, on the basis of the estimation made for nickel concentration into polycarboxylate films coated onto carbon felt (at most $0.22 \mathrm{mg}$ of nickel per $\mu \mathrm{mol}$ of carboxylic acid groups in the films), the amount of nickel metal electrodeposited in poly 1 films $\left(2.5 \times 10^{-5} \mathrm{~mol}\right.$ of malonic acid units) could be roughly estimated to a few $\mathrm{mg}$, i.e. at most $22 \mathrm{mg}$ (electrodes A and $\mathrm{C}$ : two incorporations of nickel) or $44 \mathrm{mg}$ (electrode $\mathrm{B}$ four incorporations of nickel).

Moreover, the cathodes synthesized by electroreduction of nickel ions complexed into polycarboxylate films are characterized by a significant improvement of the operational stability, as compared to cathodes prepared by electroreduction of anionic nickel-oxalate complexes incorporated by ion-exchange in cationic polymer films, which lost most of their catalytic activity after only one use. ${ }^{33}$ This behavior was attributed to the aggregation of nickel particles to form particles of larger size, leading to a decrease of the specific area of metal available for substrate absorption and hydrogenation. The synthesis of the poly $1-\mathrm{Ni}(0)$ material is performed by electroreduction of metal complexes covalently bound to the polymer matrix. This procedure can thus limit the diffusion of metal species during the electroreduction process, giving rise to a more uniform dispersion of metal throughout the polymer film, which, in turn, may lead to larger specific areas of the catalyst. Moreover, the complexing polymer can work as a stabilizer to prevent metal particles from aggregation, ${ }^{9}$ which can also explain the better stability of poly1-based cathodes.

\section{ECH at Ni-poly2 and Ni-poly3 cathodes}

The electrocatalytic hydrogenation of 2-cyclohexenone was also studied at $\mathrm{C} \mid$ poly $2-\mathrm{Ni}(0)$ and $\mathrm{C} \mid$ poly3 $3-\mathrm{Ni}(0)$ cathodes. The main results are summarized in Table 2.

Table 2. ECH of 2-cyclohexenone at C|poly2-Ni(0) and C|poly3-Ni(0) cathodes $^{\mathrm{a}}$

\begin{tabular}{|c|c|c|c|c|}
\hline Entry & Cathode ${ }^{b}$ & Products & $\begin{array}{c}\text { Product } \\
\text { yield }^{\circ} / \%\end{array}$ & $\begin{array}{c}\text { Current } \\
\text { efficiency }{ }^{\mathrm{d}} / \%\end{array}$ \\
\hline 1 & $\begin{array}{c}\text { poly } 2-\mathrm{Ni}(0)^{\mathrm{e}} \\
\left(2^{\text {nd }} \mathrm{ECH}\right)\end{array}$ & $\begin{array}{l}\text { cyclohexanone } \\
\text { cyclohexanol }\end{array}$ & $\begin{array}{l}43 \\
57\end{array}$ & 78 \\
\hline 2 & $\begin{array}{l}\text { poly } 2-\mathrm{Ni}(0)^{\mathrm{e}} \\
\left(5^{\text {th }} \mathrm{ECH}\right)\end{array}$ & $\begin{array}{l}\text { cyclohexanone } \\
\text { cyclohexanol }\end{array}$ & $\begin{array}{l}66 \\
32\end{array}$ & 65 \\
\hline 3 & $\begin{array}{l}\text { poly3-Ni }(0)^{\mathrm{f}} \\
\left(1^{\text {st }} \mathrm{ECH}\right)\end{array}$ & $\begin{array}{l}\text { cyclohexanone } \\
\text { cyclohexanol }\end{array}$ & $\begin{array}{l}42 \\
55\end{array}$ & 76 \\
\hline 4 & $\begin{array}{c}\text { poly3-Ni }(0)^{\mathrm{f}} \\
\left(2^{\text {nd }} \mathrm{ECH}\right)\end{array}$ & $\begin{array}{l}\text { cyclohexanone } \\
\text { cyclohexanol }\end{array}$ & $\begin{array}{l}36 \\
64\end{array}$ & 82 \\
\hline
\end{tabular}

${ }^{\text {a }}$ Carried out in the experimental conditions described in Table 1, note a. ${ }^{\mathrm{b}} 20 \times 25 \times 4 \mathrm{~mm}$ modified carbon felt electrodes. ${ }^{\mathrm{C}} \mathrm{GC}$ yield, measured after the consumption of 4 electrons per molecule of 2-cyclohexenone. ${ }^{\mathrm{d}}$ Calculated taking into account that reduction of 2-cyclohexenone to cyclohexanone and cyclohexanol requires 2 and 4 electrons, respectively.

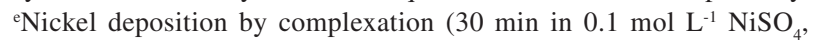
$\mathrm{pH}$ 5)-reduction (-1.4 V in $0.1 \mathrm{~mol} \mathrm{~L}^{-1} \mathrm{Na}_{2} \mathrm{SO}_{4}+0.1 \mathrm{~mol} \mathrm{~L}^{-1} \mathrm{H}_{3} \mathrm{BO}_{3}$, pH 5) in a poly2 film containing ca.1.8 $\times 10^{-5} \mathrm{~mol}$ of succinic acid units; this procedure was performed twice. ${ }^{\mathrm{f}} \mathrm{Nickel}$ deposition by complexation (30 min in $0.01 \mathrm{~mol} \mathrm{~L}^{-1} \mathrm{NiSO}_{4}$, $\mathrm{pH} 7$ )-reduction $\left(-1.5 \mathrm{~V}\right.$ in $0.1 \mathrm{~mol} \mathrm{~L}^{-1}$ $\left.\mathrm{Na}_{2} \mathrm{SO}_{4}+0.1 \mathrm{~mol} \mathrm{~L}^{-1} \mathrm{H}_{3} \mathrm{BO}_{3}, \mathrm{pH} 5.5\right)$ in a poly3 film containing ca. $3.2 \times 10^{-5} \mathrm{~mol}$ of benzoic acid units; this procedure was performed twice.

The poly(pyrrole-succinic acid)-nickel electrode material shows a catalytic activity very similar to that observed at poly(pyrrole-malonic acid)-Ni(0) film modified electrodes. For example, current efficiencies and cyclohexanol yields obtained using a Clpoly2-Ni(0) electrode (Table 2, entry 1) compare well with that obtained at a C|poly1-Ni(0) cathode synthesized in similar experimental conditions (see for example Table 1, entry 8 ). Moreover, the poly2-nickel electrode material appeared rather stable. As an example, results obtained in the course of the $5^{\text {th }} \mathrm{ECH}$ of a sample of 2-cyclohexenone at a C|poly2-Ni(0) cathode show that the current yield remained high $\left(65 \% ; 5^{\text {th }} \mathrm{ECH}\right.$ : Table 2, entry 2 ), in spite of a significant decrease in the cyclohexanol yield from $57 \%\left(2^{\text {nd }} \mathrm{ECH}\right.$; entry 1$)$ to $32 \%\left(5^{\text {th }} \mathrm{ECH}\right.$; entry 2 ). These results are very close to those obtained at a similar C|poly1-Ni(0) cathode (see for example Table 1, entry 6).

2-Cyclohexenone was also readily hydrogenated at Clpoly3-Ni(0) cathodes synthesized by complexation in $0.01 \mathrm{~mol} \mathrm{~L}^{-1} \mathrm{NiSO}_{4}(\mathrm{pH} 7)$, followed by reduction at $-1.5 \mathrm{~V}$ in clean $0.1 \mathrm{~mol} \mathrm{~L}^{-1} \mathrm{Na}_{2} \mathrm{SO}_{4}+0.1 \mathrm{~mol} \mathrm{~L}^{-1} \mathrm{H}_{3} \mathrm{BO}_{3}$ (pH 5.5), these electrodes giving even better current efficiencies (around 80\%) and cyclohexanol yields (around 60\%) than poly 1 and poly2-based materials (see Table2, entries 3 and 4). These observations confirm that the complexing 
properties of the polybenzoic acid matrix are high enough to allow synthesizing active nickel-polymer composite electrode materials.

The good catalytic activity of nickel-polybenzoic acid material synthesized this way was confirmed by the results obtained in the course of the ECH of cyclohexanone (Table 3 ) at C|poly2-Ni(0) and Clpoly3-Ni(0) cathodes synthesized in similar conditions ( 2 incorporations of nickel, using an accumulation solution in $0.01 \mathrm{~mol} \mathrm{~L}^{-1} \mathrm{NiSO}_{4}$ ). Cyclohexanol was produced with the highest yield and best current efficiency ( $86 \%$ and $43 \%$, respectively, measured after the consumption of 4 electrons per molecule of cyclohexanone) at the Clpoly3-Ni(0) cathode (Table 3, entry 3). In the same experimental conditions $\mathrm{C} \mid$ poly2-Ni(0) gave lower product and current yields (64\% and $32 \%$, respectively; Table 3, entry 1). However, the catalytic activity of poly 2 -based electrode materials was largely improved upon increasing the nickel loading. As a matter of fact, a poly 2 film in which the incorporation of nickel was completed four times allowed hydrogenating cyclohexanone with a good current efficiency (67\% measured when two electrons per molecule have been passed; Table 3, entry 2).

Table 3. ECH of cyclohexanone at C|poly2-Ni(0) and Clpoly3-Ni(0) cathodes $^{\mathrm{a}}$

\begin{tabular}{lcccc}
\hline Entry & Cathode $^{\mathrm{b}}$ & $\begin{array}{c}\text { Consumed current / } \\
\text { electron per } \\
\text { molecule }\end{array}$ & $\begin{array}{c}\text { Product } \\
\text { yield } / \%^{c}\end{array}$ & $\begin{array}{c}\text { Current } \\
\text { efficiency /\% }\end{array}$ \\
\hline 1 & poly2-Ni(0) & 2 & 30 & 30 \\
2 & 4 & 64 & 32 \\
3 & poly2-Ni(0) & 2 & 67 & 67 \\
& poly3-Ni(0) & 2 & 56 & 56 \\
4 & poly3-Ni(0) & 4 & 86 & 43 \\
& $\left(1^{\text {st }} \mathrm{ECH}\right)$ & 3 & 14 & 14 \\
5 & poly3-Ni(0) & 2 & 18 & 12 \\
& $\left(2^{\text {nd }} \mathrm{ECH}\right)$ & 4 & 06 & 06 \\
\hline
\end{tabular}

${ }^{\mathrm{a}} \mathrm{Carried}$ out in the experimental conditions described in Table 1, note a. ${ }^{\text {b }} 20 \times 25 \times 4 \mathrm{~mm}$ modified carbon felt electrodes. ${ }^{\mathrm{c} C y c l o h e x a n o l}$ GC yield. ${ }^{\mathrm{d} N i c k e l}$ deposition by complexation $\left(30 \mathrm{~min}\right.$ in $10 \mathrm{mmol} \mathrm{L}^{-1}$ $\mathrm{NiSO}_{4}, \mathrm{pH}$ 5)-reduction $\left(-1.4 \mathrm{~V}\right.$ in $0.1 \mathrm{~mol} \mathrm{~L}^{-1} \mathrm{Na}_{2} \mathrm{SO}_{4}+0.1 \mathrm{~mol} \mathrm{~L}^{-1}$ $\mathrm{H}_{3} \mathrm{BO}_{3}, \mathrm{pH}$ ) in a poly2 film containing ca.1.8 $\times 10^{-5} \mathrm{~mol}$ of succinic acid units; this procedure was performed twice. ${ }^{e}$ Electrode used in entry 1 , in which two additional incorporations of $\mathrm{Ni}(0)$ have been performed in the same conditions as described in note d. ${ }^{\mathrm{f}}$ Nickel deposition by complexation (30 min in $10 \mathrm{mmol} \mathrm{L}^{-1} \mathrm{NiSO}_{4}, \mathrm{pH}$ 7)-reduction ( $-1.5 \mathrm{~V}$ in $0.1 \mathrm{~mol} \mathrm{~L}^{-1} \mathrm{Na}_{2} \mathrm{SO}_{4}+0.1 \mathrm{~mol} \mathrm{~L}^{-1} \mathrm{H}_{3} \mathrm{BO}_{3}, \mathrm{pH} 5.5$ ) in a poly 3 film containing ca. $3.2 \times 10^{-5} \mathrm{~mol}$ of benzoic acid units; the procedure was performed

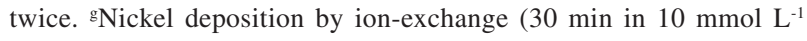
tris(ethylenediamine)nickel(II) complex, $\mathrm{pH} 8.6)$, then reduction $(-1.4 \mathrm{~V}$ in $0.1 \mathrm{~mol} \mathrm{~L}^{-1} \mathrm{H}_{3} \mathrm{BO}_{3}$ ), in a poly 3 film containing $c a .2 .2 \times 10^{-5} \mathrm{~mol}$ of benzoic acid units; this procedure was performed twice.

In contrast, modified electrodes prepared by dispersion of nickel metal in poly 3 films by ion-exchange with of tris(ethylenediamine)nickel(II), followed by the electroreductive reduction of the incorporated complex species, are characterized by very poor catalytic activity and stability. With these cathodes, the best current yields for the hydrogenation of cyclohexanone were in the range of $10 \%$ to $15 \%$. A typical result is presented in Table 3 (entry 4). Moreover, a large decrease of its catalytic efficiency was observed from the second ECH attempt (Table 3, entry 5).

All these observations were confirmed by results obtained in the course of the ECH of acetophenone under the same experimental conditions as those used with the other substrates. A series of experiments was performed at C|poly2-Ni(0) and C|poly3-Ni(0) cathodes synthesized with polymer films of similar size, containing $1.7-1.8 \times 10^{-5} \mathrm{~mol}$ of succinic or benzoic acid units, and in which increasing amounts of nickel have been incorporated by repeating the complexation-electroreduction procedure. The current and product yields for the formation of 1-phenylethanol have been measured after the consumption of 2 electrons per molecules of acetophenone The overall tendency is described as follows. The best results were obtained using Clpoly2-Ni(0) and C|poly3-Ni(0) cathodes in which nickel metal was dispersed by performing four to six times the complexation-electroreduction procedure. The amounts of nickel electrodeposited in the different polymer films could be roughly estimated at most between 16 and $24 \mathrm{mg}$ (see above). 1-Phenylethanol was produced at poly $2-\mathrm{Ni}(0)$ and poly3-Ni(0) cathodes in good yields and with rather good current efficiencies at freshly prepared electrodes $(70-75 \%$ and $65-68 \%$, respectively, measured after the consumption of 2 electrons per molecule of acetophenone). However with both electrode materials the yields decreased down to $c a .60 \%$ for the second use.

In addition, we found that the ECH of acetophenone at a poly3-Ni(0) film synthesized by ion-exchange and electroreduction of a nickel-ethylenediamine complex gave poor results. At a given charge of $2 \mathrm{~F} \mathrm{~mol}^{-1}$, the maximum amount of 1-phenylethanol was found to be $14 \%$. This last observation confirms the very low catalytic efficiency of nickel-based cathodes elaborated following this procedure, as compared to nickel-polymer composites synthesized by electroreduction of nickel complexes covalently bound to the polymer matrix.

\section{Conclusions}

In this work, different methods providing an effective dispersion of nickel particles into various electrogenerated functionalized polypyrrole were investigated, mainly by electroreduction of nickel(II) cations complexed into poly(pyrrole-carboxylate) films, and also by 
electroreduction of cationic nickel(II)-ethylenediamine complexes incorporated into polymer films through a cation-exchange process. The electrocatalytic activity and the operational stability of various composite electrode materials have been evaluated in the course of the electrocatalytic hydrogenation of ketones and enones in aqueous media. The main result is that cathodes synthesized by the electroreduction of nickel(II) ions complexed into polycarboxylate films are characterized by a higher catalytic activity and a significant improvement of the operational stability, as compared to cathodes prepared by electroreduction of nickel(II) complexes incorporated by ion-exchange into functionalized polymer films. These features could be explained by the limited diffusion of metal species in the course of the electroreduction of metal complexes covalently bound to the polymer matrix, leading to a more uniform dispersion of metal throughout the polymer film and thus increasing the specific area of the catalyst. Moreover, the complexing polycarboxylate matrix may act as a stabilizer to prevent metal particles from aggregation, which can also be responsible of the better operational stability observed for these cathodes.

Work is now in progress to manipulate the catalytic properties of the nanocomposites through the interaction of the nickel surface with functional groups of the polymer. One of our main objectives is to achieve enantioselective electrocatalytic hydrogenation with nickel-based cathodes synthesized using polymer films containing optically active polycarboxylate ligands.

\section{Acknowledgments}

Authors are thankful to CMEP (Comité Mixte d'Evaluation et de Prospective de la Coopération Interuniversitaire Franco-Algérienne; projet 03 MDU 575) for financial support.

\section{References}

1. Bönnemann, H.; Richards, R. M.; Eur. J. Inorg. Chem. 2001, 2455.

2. Rao, C. N. R.; Cheetham, A. K.; J. Mater. Chem. 2001, 11, 2887.

3. Daniel, M.-C.; Astruc, D.; Chem. Rev. 2004, 104, 293.

4. Aiken III, J. D.; Finke, R. G.; J. Mol. Catal. A: Chem. 1999, 145,1 .

5. Raimondi, F.; Scherer, G. G.; Kötz, R.; Wokaun, A.; Angew. Chem., Int. Ed. 2005, 44, 2190.

6. Welsh, C. M.; Compton, R. A.; Anal. Bioanal. Chem. 2006, 384,601 .
7. El-Sayed, M. A.; Acc. Chem. Res. 2001, 34, 257.

8. Drechsler, U.; Erdogan, B.; Rotello, V. M.; Chem. Eur. J. 2004, 10, 5571 .

9. Sergeev, G. B.; Petrukhina, M. A.; Prog. Solid State Chem. 1996, 24, 183.

10. Králik, M.; Biffis, A.; J. Mol. Catal. A: Chem. 2001, 177, 113.

11. Shenar, R.; Norsten, T. B.; Rotello, M. V.; Adv. Mater. 2005 , 17,657 .

12. Sih, B. C.; Wolf, M. O.; Chem. Commun. 2005, 3375.

13. Hepel, M.; J. Electrochem. Soc. 1998, 145, 124.

14. Gangopadhyay, R.; De, A.; Chem. Mater. 2000, 12, 608.

15. Reetz, M. T.; Helbig, W.; J. Am. Chem. Soc. 1994, 116, 7401.

16. Malinauskas, A.; Synth. Met. 1999, 107, 75.

17. Lamy, C.; Leger, J.-M.; Catalysis and Electrocatalysis at Nanoparticles Surfaces, Wieckowski, A.; Savinova, E. R.; Vayenas, C. G., eds.; Marcel Dekker: New York, 2003.

18. Tourillon, G.; Dartyge, E.; Dexpert, H.; Fontaine, A.; Jucha, A.; Lagarde, P.; Sayers, D. E.; J. Electroanal. Chem. 1984, 178, 357.

19. Lee, J. Y.; Tan T.-C.; J. Electrochem. Soc. 1990, 137, 1402.

20. Nichols, R. J.; Shröer, D.; Meyer, H.; Electrochim. Acta 1995, $40,1479$.

21. Abrantes, L. M.; Correira, J. P.; Electrochim. Acta 1996, 41, 1747.

22. Guascito, M. R.; Boffi, P.; Malitesta, C.; Sabbatini, L.; Zambonin, P. G.; Mater. Chem. Phys. 1996, 44, 17.

23. Cioffi, N.; Torsi, L.; Losito, I.; Di Franco, C.; De Bari I.; Chiavarone, L.; Scamarcio, G.; Tsakova, V.; Sabbatini, L.; Zambonin, P. G.; J. Mater. Chem. 2001, 11, 1434.

24. Abrantes, L. M.; Correira, J. P.; Surf. Coat. Technol. 1998, 107, 142.

25. Abrantes, L. M.; Correira, J. P.; Electrochim. Acta 2000, 45, 4179.

26. Navarro-Flores, E.; Omanovic, S.; J. Mol. Catal. A: Chem. 2005, 242, 182.

27. Haseko, Y.; Shrestha, N. K.; Teruyama, S.; Saji, T.; Electrochim. Acta 2000, 45, 4179.

28. Venkatachalam, K.; Gavalas, V. G.; Xu, S.; De Leon, A. C.; Bhattacharya, D.; Bacahas, L. G.; J. Nanosci. Nanotechnol. 2006, 6, 2408.

29. Moutet. J.-C.; Org. Prep. Proced. Int. 1992, 24, 309.

30. Chapuzet, J. M.; Lasia, A.; Lessard, J.; Electrocatalysis, Lipkowski, J.; Ross, P. N., eds.; Wiley-VCH: New York, 1998, p. 155.

31. Jović, V. D.; Trišović, T.; Jović, B. M.; Vojnović, M.; J. Electroanal. Chem. 1996, 408, 149.

32. Zouaoui, A.; Stephan, O.; Carrier, M.; Moutet, J.-C.; J. Electroanal. Chem. 1999, 474, 113.

33. Zouaoui, A.; Stephan, O.; Ourari, A.; Moutet, J.-C.; Electrochim. Acta 2000, 46, 49.

34. Zouaoui, A.; Moutet, J.-C.; Electrochim. Acta 2001, 46, 4035. 
35. Heitzmann, M.; Brovelli, F.; Basaez, L.; Bucher, C.; Limosin, D.; Pereira, E.; Rivas, B. L.; Royal, G.; Saint-Aman, E.; Moutet, J.-C.; Electroanalysis 2005, 17, 1970.

36. Heitzmann, M.; Bucher, C.; Moutet, J.-C.; Pereira, E.; Rivas, B. L.; Royal, G.; Saint-Aman, E.; J. Electroanal. Chem. 2007, 610, 147.

37. Shiraishi, Y.; Nakayama, M.; Takagi, E.; Tominago, T.; Toshima, N.; Inorg. Chim. Acta 2000, 300, 924, and references therein.

38. Deronzier, A.; Marques, M. J.; J. Electroanal. Chem. 1989, 265, 341.

39. Guzzo, P. R.; Miller, M. J.; J. Org. Chem. 1994, 59, 4862.

40. De Oliveira, I. M. F.; Moutet, J.-C.; Hamar-Thibault, S.; J. Mater. Chem. 1992, 2, 167.

41. Stephan, O.; Carrier, M.; Le Bail, M.; Deronzier, A.; Moutet, J.-C.; J. Chem. Soc., Faraday Trans. 1995, 91, 1241.

42. Martell, A. E.; Smith, R. M.; Critical Stability Constants, Plenum Press: New York, 1977.

43. Gamburg, Y. D.; Grosheva, M. Y.; Biallozor, S.; Hass, M.; Surf. Coat. Technol. 2002, 150, 95.
44. Hoare, J. P.; J. Electrochem. Soc. 1987, 134, 3102.

45. Melendres, C. A.; Tani, B. S.; J. Electrochem. Soc. 1990, 137, 1060.

46. Schwarzenbacher, G.; Naf, R.; Schitter, R.; Hummel, K.; Synth. Met. 1999, 101, 143.

47. Peganova, N. V.; Kravtsov, V. I.; Astakhova, R. K.; Russ. J. Electrochem. 2002, 38, 1461.

48. Harris, T. M.; Wilson, J. L.; Bleakley, M.; J. Electrochem. Soc. 1999, 146, 1461.

49. Pizarro, G. D. C.; Marambio, O. G.; Jeria-Orell, M.; Huerta, M. R.; Rodríguez, O. O.; Rivas, B. L.; Geckeler, K. E.; J. Appl. Polym. Sci. 2007, 105, 2893.

50. Ma, J. C.; Dougherty, D. A.; Chem. Rev. 1997, 97, 1303.

51. Zielke, U.; Hüttinger, K. J.; Hoffman, W. P.; Carbon 1996, 8, 983.

52. Mahdavi, B.; Chambrion, P.; Binette, J.; Martel, E.; Lessard, J.; Can. J. Chem. 1995, 73, 846.

53. Yamada, Y.; Osa, T.; Matsue, T.; Chem. Lett. 1987, 1611.

Received: December 23, 2008

Web Release Date: August 28, 2009 